OPEN ACCESS

Edited by:

Jinqiang Zhang,

Chongqing University, China

Reviewed by:

Huan Wang,

Nanjing University, China

Chuanliu Wu,

Xiamen University, China

*Correspondence:

Li Fan

smmuxlb@163.com

Hong-Gang Hu

hhu66@shu.edu.cn

†These authors have contributed equally to this work

Specialty section:

This article was submitted to Medicinal and Pharmaceutical

Chemistry,

a section of the journal

Frontiers in Chemistry

Received: 11 October 2020 Accepted: 11 November 2020 Published: 10 December 2020

Citation:

Wang $N$, Xie G, Liu C, Cong W, He S, Li Y, Fan L and Hu H-G (2020) Design,

Synthesis, and Antitumor Activities

Study of Stapled A4K14-Citropin 1.1 Peptides. Front. Chem. 8:616147. doi: 10.3389/fchem.2020.616147

\section{Design, Synthesis, and Antitumor Activities Study of Stapled A4K14-Citropin 1.1 Peptides}

\author{
Nan Wang ${ }^{1 \dagger}$, Gang Xie ${ }^{2 \dagger}$, Chao $\mathrm{Liu}^{3+}$, Wei Cong ${ }^{1}$, Shipeng $\mathrm{He}^{1}$, Yinghua $\mathrm{Li}^{1}$, Li Fan ${ }^{3 *}$ and \\ Hong-Gang $\mathrm{Hu}^{\text {** }}$
}

${ }^{1}$ Institute of Translational Medicine, Shanghai University, Shanghai, China, ${ }^{2}$ Department of Orthopedics, The Second Affiliated Hospital, Shantou University Medical College, Shantou, China, ${ }^{3}$ School of Pharmacy, Second Military Medical University, Shanghai, China

A4K14-citropin 1.1 is a structurally optimized derivative derived from amphibians' skin secreta peptide Citropin, which exhibits broad biological activities. However, the application of A4K14-citropin 1.1 as a cancer therapeutic is restricted by its structural flexibility. In this study, a series of all-hydrocarbon stapled peptides derivatives of A4K14-citropin 1.1 were designed and synthesized, and their chemical and biological characteristics were also investigated. Among them, A4K14-citropin 1.1-Sp1 and A4K14-citropin 1.1-Sp4 displayed improved helicity levels, greater protease stability, and increased antitumor activity compared with the original peptide, which establishes them as promising lead compounds for novel cancer therapeutics development. These results revealed the important influence of all-hydrocarbon stapling side chain on the secondary structure, hydrolase stability, and biological activity of A4K14-citropin 1.1.

Keywords: A4K14-citropin 1.1, all-hydrocarbon stapled peptides, anti-tumor activity, peptidomimetic, animal toxin

\section{INTRODUCTION}

Malignant tumors are one of leading causes of death worldwide investigated by the World Health Organization (WHO) (Murray and Lopez, 2013). There were more than 12 million cancer cases and 7 million cancer deaths occurring in both male and female individuals in 2008 worldwide; the same numbers reached 15 and 8.8 million, respectively, in 2015 (Torre et al., 2011). Cancer has, therefore, become a major public health issue and a leading cause of human mortality (Kobayashi et al., 2002; Ross and Small, 2002; Tong et al., 2018). While small-molecule anticancer drugs have achieved a certain effect, the application of chemotherapy is restricted by a large number of side effects, for example, liver, kidney, and gastrointestinal toxicity; hair loss; diarrhea; breathing troubles; and respiratory difficulties (Lee et al., 2013). Because of their interesting chemical structures and extensive biological activity, peptides have attracted a significant amount of attention (Henninot et al., 2018).

The antimicrobial peptide (AMP) belongs to the membrane-active peptides family that exhibits antibacterial, antitumor, antiviral, and other biological activities due to its cell membrane perforating ability that destroys the structure of the cell membrane 


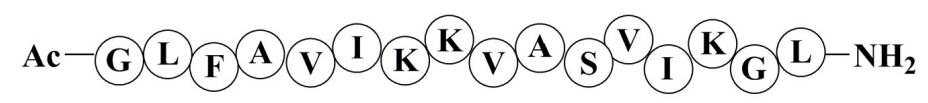

A4K14-citropin 1.1

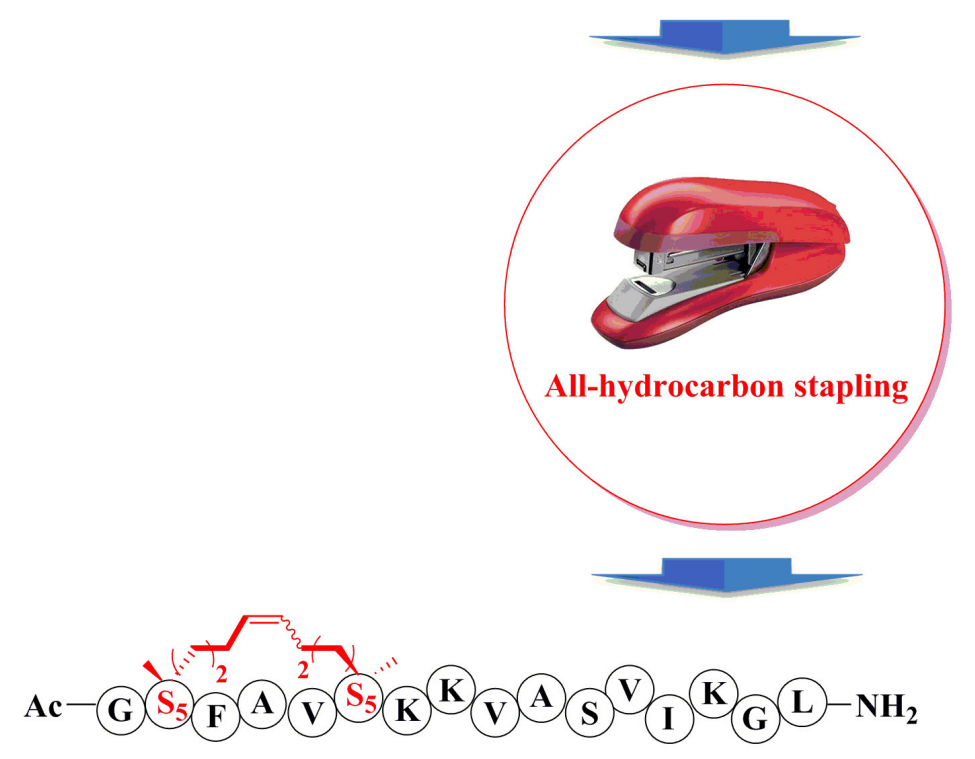

A4K14-citropin 1.1-Sp1

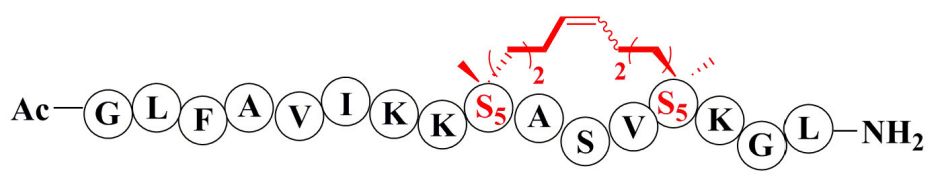

Improved helicity level

Greater protease stability

Increased anti-tumor activity

\section{A4K14-citropin 1.1-Sp4}

GRAPHICAL ABSTRACT |

and then causes intracellular material leaking out and ultimate cell death (Lohner, 2017). Citropin (GLFDVIKKVASVIGGL), obtained from amphibians' skin secreta, is an $\alpha$-helix containing 16-residue AMP. A previous study showed that Citropin exhibits broad biological activities such as antibacterial, antitumor, and neuronal nitric oxide synthase (nNOS) inhibition. In a structure activity relationships (SAR) study, Bowie and his team found that replacement of Asp4 and Gly14 with Ala and Lys (termed A4K14citropin 1.1) resulted in a more stable $\alpha$-helix than Citropin on the C-terminal section, and it led to better biological activities (Doyle et al., 2003). Hence, A4K14-citropin 1.1 (GLFAVIKKVASVIKGL) has become a potential antitumor leading compound. However, linear peptides hardly retain their native conformation and binding capability owing to their poor structural reinforcement, and they cannot resist proteolytic degradation and cross the cell membrane, which were closely related to AMP's biological activity because of their cell-membrane hole-punching mechanism (Marr et al., 2006; Mourtada et al., 2019). Therefore, a linear peptide itself is a poor therapeutic candidate.
It was reported that increased helicity, hydrophobicity, and penetrating ability of AMP within a certain range could improve their biological activity (Pouny et al., 1992; Dathe et al., 1997; Wieprecht et al., 1997; Dathe and Wieprecht, 1999; Avrahami and Shai, 2002; Shang et al., 2012). For these reasons, we believe that synthetic methods reinforcing their native $\alpha$-helix conformation, thereby restoring binding affinity, is an effective strategy for AMP optimization. Among these methods, peptide stapling is one of the most established ones for generating $\alpha$ helices. The macrocyclization process could improve structural rigidity and reinforce the desired $\alpha$-helical conformation of the peptide, resulting in enhanced protease resistance and improved cell-penetrating ability (Cui et al., 2013; Mortensen et al., 2019; Kannan et al., 2020; Li et al., 2020). Besides, the aliphatic side chain could effectively improve the structural hydrophobicity of peptides. All-hydrocarbon stapled peptides, which involve the ring-closing metathesis of olefin-bearing amino acids developed by Verdine et al., have made the greatest influence on this field so far (Schafmeister et al., 2000). The literature is replete with reports that an all-hydrocarbon stapled strategy is an effective method for peptidomimetics development (Bird et al., 
2010; Chapuis et al., 2012; Walensky and Bird, 2014; Liu et al., 2020). In the work reported herein, various derivatives using all-hydrocarbon peptide-stapled strategy were designed and synthesized to increase the cell permeability, membrane aggregation, protease stability, structural hydrophobicity, and antitumor activity of A4K14-citropin 1.1.

\section{EXPERIMENTAL SECTION}

\section{General Information}

Trifluoracetic acid (TFA), N,N-diisopropylethylamine (DIPEA), O-(6-chloro-1-hydrocibenzotrizol-1-yl)-1,1,3,3tetramethyluronium hexafluorophosphate (HCTU), dichloroethane, first-generation Grubbs' reagent, phenol, triisopropylsilane (TIPS), and diethyl ether were purchased from Acros, TCI, Adamas. All Fmoc-protected amino acids were bought from GL Biochem Shanghai Co. Ltd. Rink amide resin (loading $0.15 \mathrm{mmol} / \mathrm{g}$ ) was purchased from Tianjin Nankai Hecheng S\&T Co., Ltd. Dichloromethane (DCM), dichloroethane (DCE), N,N-dimethylformamide (DMF), and acetonitrile used were bought from Sinopharm Chemical Reagent Co. Ltd. Peptides were analyzed and purified by reverse phase high-performance liquid chromatography (HPLC) (RPHPLC, Shimadzu) using C18 column. The solvent systems were buffer $\mathrm{A}\left(0.1 \%\right.$ TFA in $\left.\mathrm{CH}_{3} \mathrm{CN}\right)$ and buffer $\mathrm{B}(0.1 \%$ TFA in water). High-resolution mass spectra (HR-MS) were measured on a Waters Xevo G2 QTOF mass spectrometer. Circular dichroism data were recorded using a JASCO J-820 spectropolarimeter (JASCO Corp., Ltd).

\section{General Procedures for the Fmoc Solid-Phase Peptide Synthesis}

Peptides were synthesized with Fmoc solid-phase peptide synthesis (SPPS) on rink amide resin (initial loading $=0.15$ mmol) manually. Fmoc deprotection was realized using 20\% piperidine in DMF for $10 \mathrm{~min}$ at room temperature. Amino acids (0.45 mmol) coupling was carried out by HCTU $(0.45 \mathrm{mmol})$ and DIPEA $(1.35 \mathrm{mmol})$ in DMF solution for $30 \mathrm{~min}$ at room temperature. Olefin metathesis reaction was realized using first generation Grubbs' reagent $(0.45 \mathrm{mmol})$ in dry dichloroethane solution for $4 \mathrm{~h}$ at room temperature. Peptides cleavage was carried out by $\mathrm{B}$ cocktail (TFA/TIPS/phenol/ $\mathrm{H}_{2} \mathrm{O}=88: 5: 5: 2$, $\mathrm{v} / \mathrm{v} / \mathrm{v} / \mathrm{v}$ ) for $2 \mathrm{~h}$ at room temperature. Then, the cleavage cocktail was collected, and the chilled diethyl ether was added. The resulting crude peptide was analyzed and purified by RP-HPLC.

\section{A4K14-Citropin 1.1}

$169 \mathrm{mg}, 67 \%$ yield. HR-MS m/z calcd. for $\mathrm{C}_{81} \mathrm{H}_{142} \mathrm{~N}_{20} \mathrm{O}_{18}$ $1,683.0811 ;$ found $[\mathrm{M}+2 \mathrm{H}]^{2+}=842.5535 ;[\mathrm{M}+3 \mathrm{H}]^{3+}$ $=562.3758$.

\section{A4K14-Citropin1.1-Sp1}

$161 \mathrm{mg}, 63 \%$ yield. HR-MS m/z calcd. for $\mathrm{C}_{83} \mathrm{H}_{142} \mathrm{~N}_{20} \mathrm{O}_{18}$ 1,707.0811; found $[\mathrm{M}+2 \mathrm{H}]^{2+}=855.0585 ;[\mathrm{M}+3 \mathrm{H}]^{3+}$ $=570.0455$.

A4K14-Citropin1.1-Sp2

$161 \mathrm{mg}, 62 \%$ yield. HR-MS m/z calcd. for $\mathrm{C}_{85} \mathrm{H}_{146} \mathrm{~N}_{20} \mathrm{O}_{18}$ $1,735.1124 ;$ found $[\mathrm{M}+2 \mathrm{H}]^{2+}=869.0642 ;[\mathrm{M}+3 \mathrm{H}]^{3+}$ $=579.7188$.

\section{A4K14-Citropin1.1-Sp3}

$186 \mathrm{mg}, 71 \%$ yield. HR-MS m/z calcd. for $\mathrm{C}_{86} \mathrm{H}_{148} \mathrm{~N}_{20} \mathrm{O}_{18}$ $1,749.1280$; found $[\mathrm{M}+2 \mathrm{H}]^{2+}=876.0834 ;[\mathrm{M}+3 \mathrm{H}]^{3+}$ $=584.4036$.

A4K14-Citropin1.1-Sp4

$170 \mathrm{mg}, 66 \%$ yield. HR-MS m/z calcd. for $\mathrm{C}_{84} \mathrm{H}_{144} \mathrm{~N}_{20} \mathrm{O}_{18}$ $1,721.0967 ;$ found $[\mathrm{M}+2 \mathrm{H}]^{2+}=862.0619 ;[\mathrm{M}+3 \mathrm{H}]^{3+}$ $=575.0512$.

\section{A4K14-Citropin1.1-Sp5}

$166 \mathrm{mg}, 62 \%$ yield. HR-MS m/z calcd. for $\mathrm{C}_{90} \mathrm{H}_{156} \mathrm{~N}_{20} \mathrm{O}_{17}$ 1,789.1957; found $[\mathrm{M}+2 \mathrm{H}]^{2+}=896.1107 ;[\mathrm{M}+3 \mathrm{H}]^{3+}$ $=597.7472$.

\section{A4K14-Citropin1.1-Sp6}

$166 \mathrm{mg}, 63 \%$ yield. HR-MS m/z calcd. for $\mathrm{C}_{87} \mathrm{H}_{150} \mathrm{~N}_{20} \mathrm{O}_{18}$ 1,763.1437; found $[\mathrm{M}+2 \mathrm{H}]^{2+}=883.0813 ;[\mathrm{M}+3 \mathrm{H}]^{3+}$ $=589.0584$.

\section{A4K14-Citropin1.1-Sp7}

$162 \mathrm{mg}, 62 \%$ yield. HR-MS m/z calcd. for $\mathrm{C}_{86} \mathrm{H}_{148} \mathrm{~N}_{20} \mathrm{O}_{18}$ $1,749.1280 ;$ found $[\mathrm{M}+2 \mathrm{H}]^{2+}=875.5751 ;[\mathrm{M}+3 \mathrm{H}]^{3+}$ $=584.0531$.

\section{Protease Stability Experiment}

Fifty microliters peptides in dimethyl sulfoxide (DMSO) (1 mM) and $1,950 \mu \mathrm{l} \alpha$-chymotrypsin in phosphate-buffered saline (PBS) (0.5 ng/ $\mu \mathrm{l}, \mathrm{pH} 7.4$, containing $2 \mathrm{mM} \mathrm{CaCl}_{2}$ ) were mixed and incubated at $37^{\circ} \mathrm{C}$. After $0,1,2,4,8$, and $12 \mathrm{~h}$, the percent residual peptide was monitored by HPLC.

\section{Spectroscopy Study}

Peptides in 50\% 2,2,2-trifluoroethanol (TFE) aqueous solution $(0.1 \mathrm{mg} / \mathrm{ml})$ were recorded at $20^{\circ} \mathrm{C}$ in a quartz cell of $10 \mathrm{~mm}$ path length. Percent helicity was calculated by the follow equation (Wang et al., 2006):

$$
\alpha=\frac{[\theta]_{222}}{[\theta]_{\max }} \times 100 \%
$$

$[\theta]_{222}$ is the molar ellipticity of $222 \mathrm{~nm} ;[\theta]_{\max }=(-44,000+$ $250 \mathrm{~T})(1-\mathrm{k} / \mathrm{n}), \mathrm{k}=4$, where $\mathrm{n}$ is the numbers of amino acids and $\mathrm{T}=20^{\circ} \mathrm{C}$.

\section{Cell Culture and Cell Viability Assay}

The human prostate cancer cell line C4-2B was kindly provided and authenticated by Dr. Leland Chung (Cedars-Sinai Medical Center, Los Angeles, CA, USA). The human lung tumor cell line A549, the human breast tumor cell line MCF-7, and glioma cell line U87 were obtained from Shanghai Cellular Institute of Chinese Academy of Sciences (Shanghai, China). All cell lines were maintained in Dulbecco's modified Eagle's medium (DMEM) involving 10\% fetal bovine serum (FBS) and $1 \%$ penicillin-streptomycin (PS) (complete DMEM) and was cultured at $37^{\circ} \mathrm{C}$ with humidified atmosphere of $5 \% \mathrm{CO}_{2}$. Cell viability was examined using the cell counting kit (CCK-8) in accordance with manufacturer's protocol. Cells were seeded in 96-well culture plates at a density of $3 \times 10^{3}$ cells/well at $37^{\circ} \mathrm{C}$ for $24 \mathrm{~h}$. Next day, cells were treated without or with various concentrations $(0.39,0.78,1.56,3.125,6.25,12.5,25$, and $50 \mu \mathrm{M})$ of peptides for $96 \mathrm{~h}$ after which $10 \mu \mathrm{l}$ of CCK- 8 reagent was added 


\section{Peptide}

A4K14-citropin1.1

A4K14-citropin1.1-Sp1

A4K14-citropin1.1-Sp2

A4K14-citropin1.1-Sp3

A4K14-citropin1.1-Sp4

A4K14-citropin1.1-Sp5

A4K14-citropin1.1-Sp6

A4K14-citropin1.1-Sp7
Sequence

Ac-GLFAVIKKVASVIKGL-NH

Ac-GS $_{5}$ FAVS $_{5} \mathrm{KKVASVIKGL-NH}_{2}$

Ac-GLFAS ${ }_{5}$ IKKS $_{5}$ ASVIKGL-NH

$\mathbf{S}_{5}$ :<smiles>C=CCCC[C@](C)(N)C(=O)O</smiles>

(S)-2-(4-pentenyl)alanine

$\operatorname{Ac-GLFAVS}_{5} \mathrm{KKVS}_{5}$ SVIKGL-NH

Ac-GLFAVIKKS ${ }_{5} \mathrm{ASVS}_{\mathbf{5}} \mathrm{KGL-NH}_{2}$

$\mathbf{R}_{\mathbf{8}}$ :

Ac-GLFAVIKKVAS ${ }_{5}$ IIKS $_{5} \mathrm{~L}^{-N_{2}}$

Ac-GR ${ }_{\mathbf{8}}$ FAVIKKS $_{5}$ ASVIKGL-NH<smiles>C=CCCCCCCC(C)(N)C(=O)O</smiles>

(R)-2-(7-octenyl)alanine

FIGURE 1 | Structures of A4K14-citropin 1.1 and stapled derivatives. The key residues are colored red, and $\mathrm{S}_{5} / \mathrm{S}_{5}$ and $\mathrm{R}_{8} / \mathrm{S}_{5}$ were cross-linked by ring-closing metathesis (RCM).

to each well and incubated for further $2 \mathrm{~h}$ at $37^{\circ} \mathrm{C}$. The optical density (OD) was then measured at a wavelength of $450 \mathrm{~nm}$ on a Cell Imaging Multi-Mode Reader (BioTek, Vermont, USA), and the average OD values for each sample were analyzed using Image-J software (NIH, Bethesda, MD, USA). The half maximal inhibitory concentration ( $\mathrm{IC}_{50}$ ) was calculated by GraphPad Prism v7.0 software (San Diego, CA, USA).

\section{Scratch-Wound Healing Assay}

A549 cell line was allowed to grow until a confluent monolayer was observed. After being serum starved overnight, using a sterilized micropipette tip, a linear scratch wound was created across the diameter of the well, splitting the cell monolayer in two. Cellular debris was removed by gentle washing with PBS. The remains were then incubated with fresh low-serum (2\% FBS) DMEM without or with $5 \mu \mathrm{M}$ of A4K14-citropin 1.1 or A4K14-citropin 1.1-Sp4. Immediately, phase contrast images were captured for each scratch wound and used as starting reference point (day 0). Further phase contrast images were captured 1 and 2 days after peptides treatment. The reduction in the scratch-wound area was calculated.

\section{Transwell Migration Assay}

The effect of A4K14-citropin 1.1 upon cancer cells migrating was evaluated using the Transwell permeable support filters $(8 \mu \mathrm{m}$ pore size, 12-well format; Corning Inc., Corning, NY, USA). Briefly, $6 \times 10^{4}$ cells/well of A549 cells were seeded into the upper chamber of the Transwell inserts in low-serum (2\% FBS) DMEM with the concentration of 0 or $5 \mu \mathrm{M}$ of A4K14-citropin 1.1 or A4K14-citropin 1.1-Sp4. Next, the lower chambers were full of complete DMEM and cells incubated at $37^{\circ} \mathrm{C}$ for $24 \mathrm{~h}$. Finally, cells in the upper chamber inserts were gently washed with PBS twice and gently wiped with cotton swabs to remove nonmigrating cells. Migrated cells were washed briefly, fixed, and subsequently dyed and counted.

\section{RESULTS AND DISCUSSION Design of Stapled A4K14-Citropin 1.1 Peptides}

To design all-hydrocarbon peptidomimetics of A4K14-citropin 1.1, modification of the key residues that are significant for biological activities of A4K14-citropin 1.1 should be avoided. 


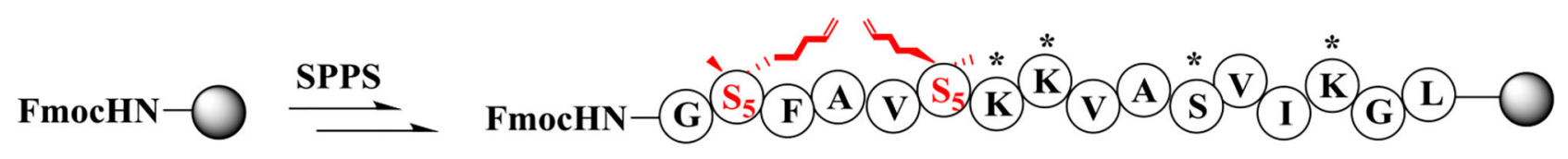

The resin-bound peptides were protected on side chains at asterisk sites.
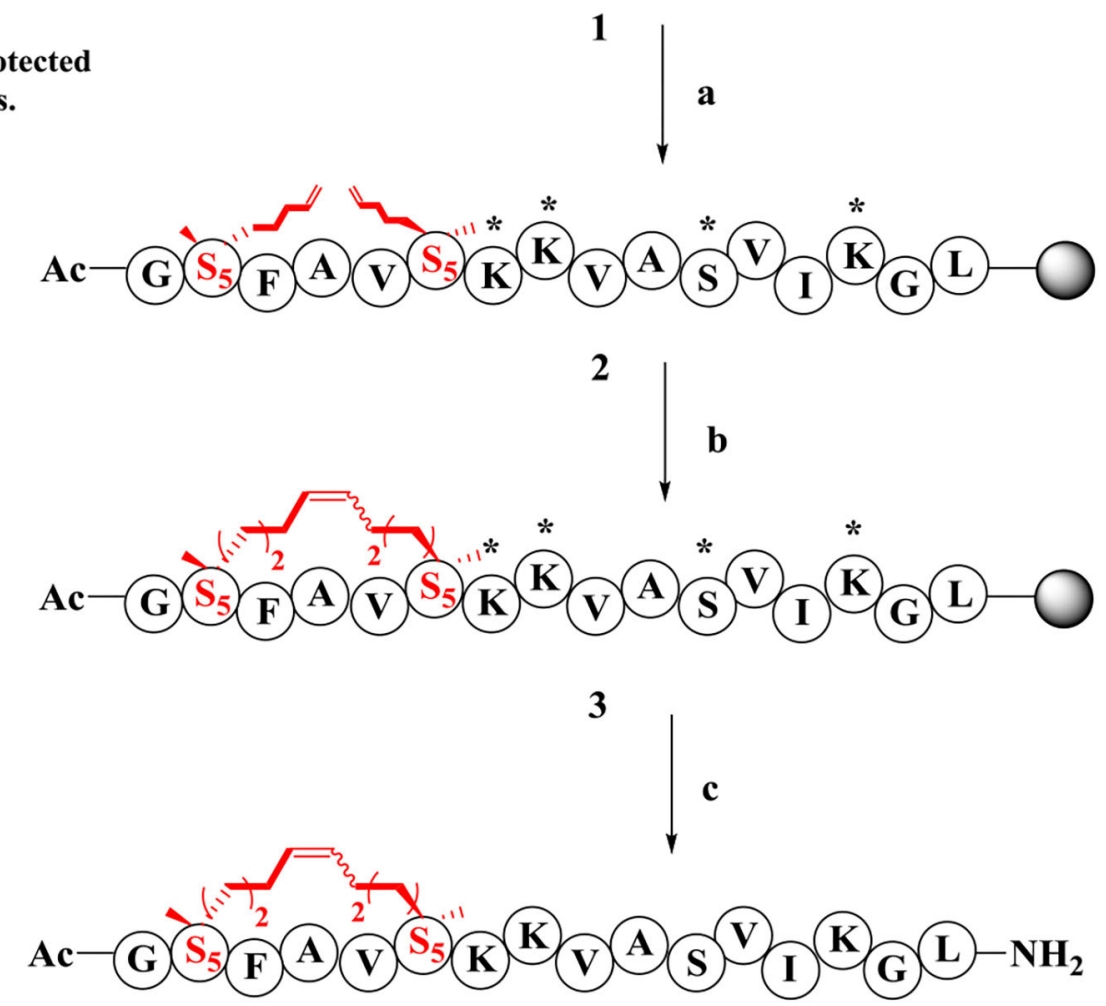

\section{A4K14-citropin 1.1-Sp1}

SCHEME 1 | Synthesis route of A4K14-citropin 1.1-Sp1. (a) (i) 20\% piperdine/DMF, 20 min, rt; (ii) pyridine/Ac $\mathrm{O}_{2} \mathrm{O}(1: 1, v / v), 20$ min, rt; (b) first generation Grubbs' reagent, DCE, $2 \mathrm{~h}$, rt; (c) TFATIPS/phenol/ $\mathrm{H}_{2} \mathrm{O}=88: 5: 5: 2, \mathrm{~V} / \mathrm{V} / \mathrm{V} / \mathrm{v}, 2 \mathrm{~h}, \mathrm{rt}, 63 \%$.

According to a previous study, Gly1, Phe3, Ala4, Lys7, and Leu16 are necessary to remain its biological activities, so in this work, these residues were left intact and A4K14-citropin 1.1-Sp1-5 was designed by introducing (S)-2-(4-pentenyl) alanine amino acid $\left(\mathrm{S}_{5}\right)$ with an $\mathrm{i}+4$ strategy. Additionally, (R)-2-(7-octenyl) alanine amino acid $\left(\mathrm{R}_{8}\right)$ and $(\mathrm{S})$-2-(4-pentenyl) alanine amino acid $\left(\mathrm{S}_{5}\right)$ were incorporated at the $\mathrm{i}$ and $\mathrm{i}+7$ positions to obtain A4K14-citropin 1.1-Sp6-7 (Figure 1).

\section{Synthesis and Characterization of Stapled A4K14-Citropin 1.1 Peptides}

The synthesis of stapled peptides was started from the rink amide $\mathrm{AM}$ resin (loading $=0.33 \mathrm{mmol} / \mathrm{g}$ ) as shown in Scheme 1. Normal amino acids, Fmoc-(S)-2-(4-pentenyl)Ala$\mathrm{OH}\left(\right.$ Fmoc-S $\left._{5}-\mathrm{OH}\right)$ and Fmoc-(R)-2-(7-octenyl)Ala-OH (Fmoc$\left.\mathrm{R}_{8}-\mathrm{OH}\right)$, were introduced into the peptide backbone on resin using HCTU as the coupling reagent to provide Fmoc-protected on-resin peptide 1. After Fmoc deprotection and N-terminal acetylation, intramolecular macrocyclization of on-resin peptide
2 was successfully accomplished with the first-generation Grubbs' reagent in DCE solution to obtain the on-resin stapled peptide 3. Finally, acidic cleavage and concomitant global deprotection using reagent $\mathrm{B}(\mathrm{TFA} / \mathrm{TIPs} /$ phenol/water $=88: 5: 5: 2, v / v / v / v)$ yielded the crude target peptidomimetic A4K14-citropin 1.1-Sp1. Further analysis and purification were achieved by RP-HPLC. Crude products could be easily purified to more than $95 \%$ purity, and the yields ranged from 60 to $75 \%$. Then, all of the molecular weights were confirmed by HR-MS and were identical to the theoretical molecular mass.

\section{Helicity Degree and Protease Stability Analysis of Stapled A4K14-Citropin 1.1 Peptides}

The secondary structure of these stapled peptides was measured by circular dichroism (CD). CD analysis indicates that the helicity of initial A4K14-citropin 1.1 was $61.5 \%$ and that of the stapled peptides ranged from 13.6 to $89.8 \%$ (Figure 2 and Table 1). 
A

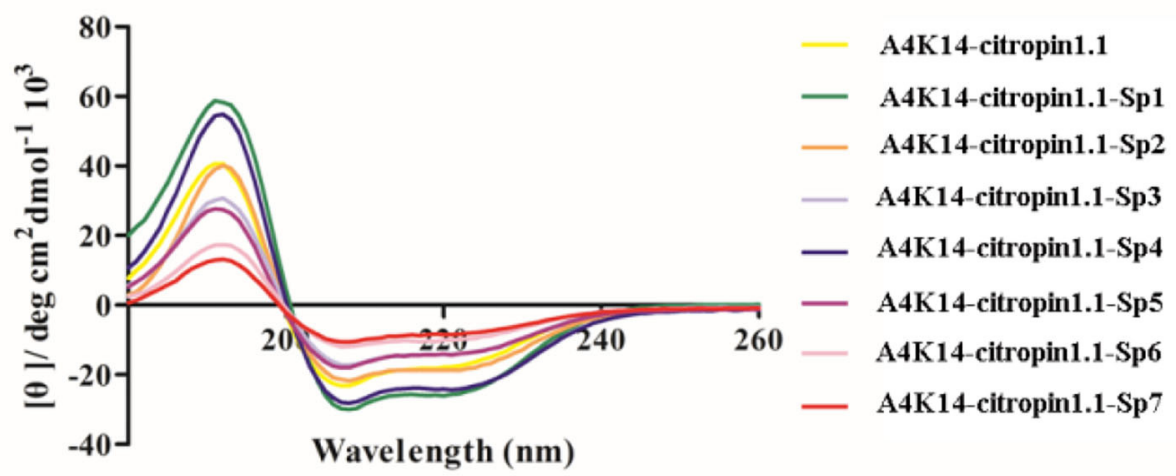

B
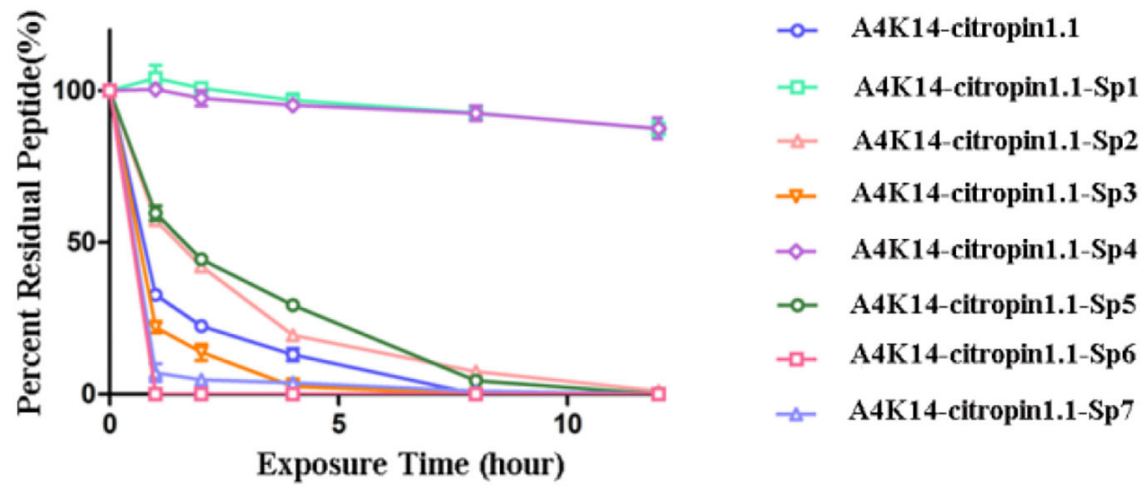

FIGURE 2 | (A) The circular dichroism data of A4K14-citropin 1.1 and stapled derivatives. (B) Proteolytic stability of A4K14-citropin 1.1 and stapled derivatives under $\alpha$-chymotrypsin treatment.

TABLE 1 | $\alpha$-Helicity, degradation half-life, and antitumor activity of A4K14-citropin 1.1 and stapled derivatives.

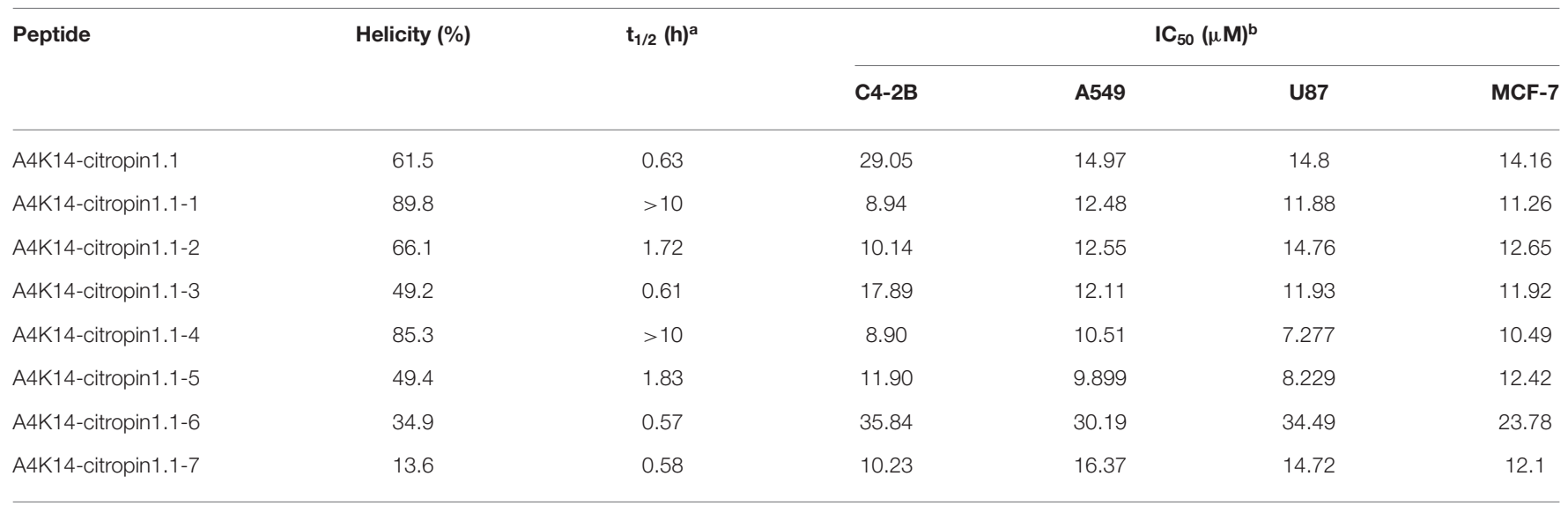

${ }^{a}$ Hydrolysis enzyme degradation half-life.

${ }^{b}$ Half maximal inhibitory concentration. 
A
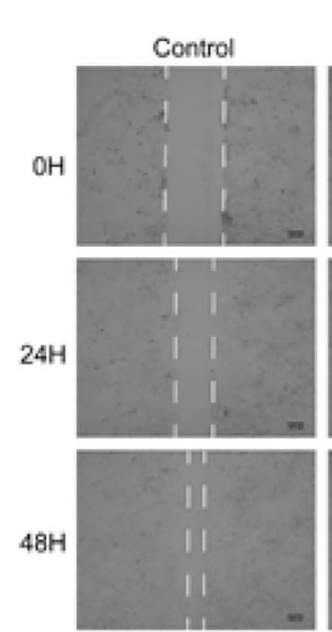

C

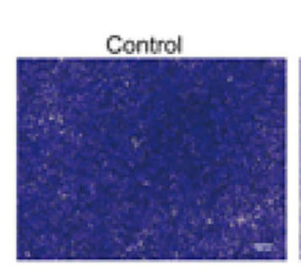

A4K14-citro
$5 \mu \mathrm{M}$
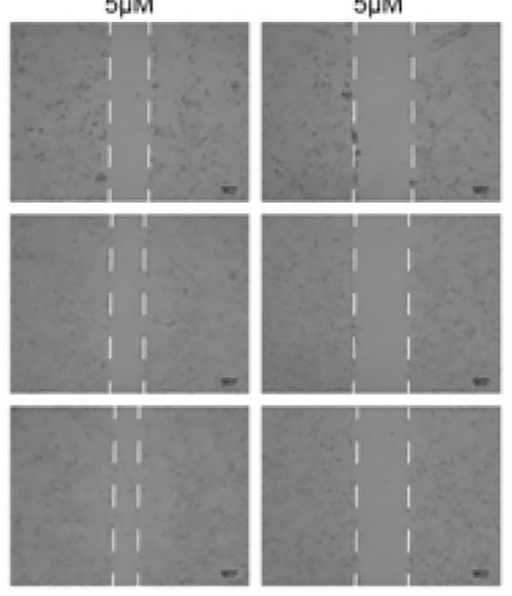

B

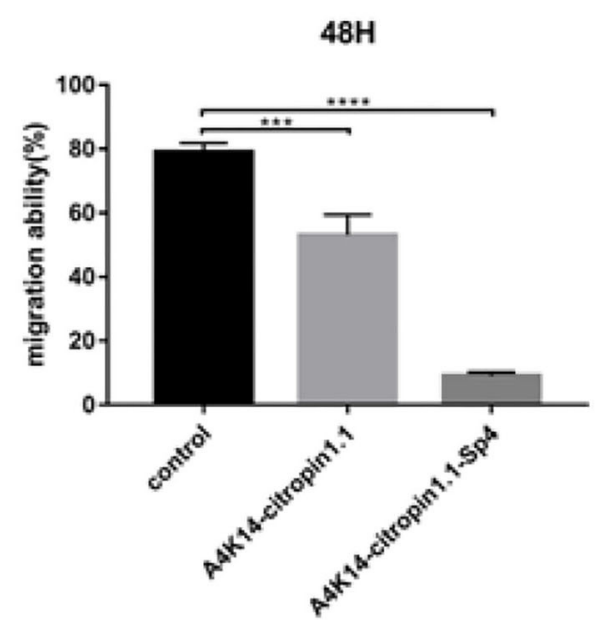

D

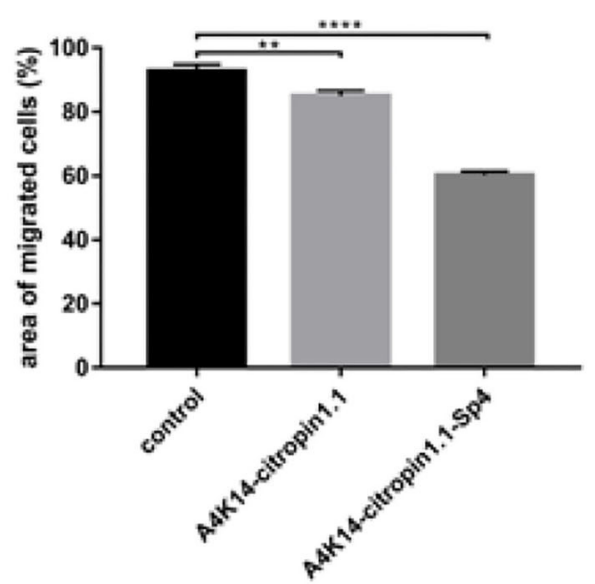

FIGURE 3 | Monolayer A549 cells were wounded using a sterilized micropipette tip subsequently treated with indicated concentration of A4K14-citropin 1.1 or A4K14-citropin 1.1-Sp4 for $48 \mathrm{~h}$; (A) the images of wound at each point were recorded. (B) The reduction in the scratch-wound area was calculated. (C) A549 cells that had passed through the 8- $\mu \mathrm{m}$ polycarbonate membrane without the Matrigel following treatment with the indicated concentrations of A4K14-citropin 1.1 or A4K14-citropin 1.1-Sp4 for $24 \mathrm{~h}$. (D) Quantification analysis of the area of the migrated A549 cells. Scale bars: $100 \mu \mathrm{m}$ (Data are presented as the mean \pm standard deviation; $n=3$; ${ }^{\star} p<0.05,{ }^{* \star} p<0.01,{ }^{\star \star *} p<0.001,{ }^{\star * \star \star} p<0.0001$ vs. the control group).

These results suggested that peptide stapling strategy can effectively optimize the helicity level compared with their linear compartment if the all-hydrocarbon side chains were at the proper position. Among them, A4K14-citropin 1.1-Sp1 and A4K14-citropin 1.1-Sp4 displayed the top 2 degrees of helicity ( 89.8 and $85.3 \%$, respectively) in the aqueous solution and acquired 1.46- and 1.38-fold improvements compared to A4K14citropin 1.1, respectively. A further protease stability experiment was conducted using an $\alpha$-chymotrypsin-mediated degradation test. It was found that, after $12 \mathrm{~h}$ of protease exposure, A4K14citropin 1.1, A4K14-citropin 1.1-Sp2-3, and A4K14-citropin 1.1Sp5-7 were degraded completely, while more than 85\% of A4K14citropin 1.1-Sp1 and A4K14-citropin 1.1-Sp4 remained intact, suggesting greater protease stability over other peptides (Figure 2 and Table 1).

\section{Antitumor Activity Test of Stapled A4K14-Citropin 1.1 Peptides}

After A4K14-citropin 1.1 and its analogs were synthesized, their antitumor activities were tested using the CCK-8 test with the human prostate cancer cell line $\mathrm{C} 4-2 \mathrm{~B}$, the human NSCLC cell line A549 (adenocarcinoma), the human breast tumor cell line MCF-7, and the glioma cell line U87. The results are summarized in Table 1. It was found that all of the stapled peptides exhibited enhanced activity compared with prototype peptide A4K14-citropin 1.1 (Table 1). Among them, 
A4K14-citropin 1.1-Sp4 exhibited the best inhibition activity. For further study, we illustrated the inhibitions of A4K14citropin 1.1-Sp4 upon metastatic characteristic of malignant lung cancer cells by the scratch-wound horizontal-migration (Figures 3A,B) as well as the Transwell vertical-migration assays (Figures 3B-D). In the scratch-wound horizontal-migration assay, A549 cells treated with A4K14-citropin 1.1-Sp4 revealed a better decreased ability to migrate across and close the scratch wound. Similarly, in the Transwell vertical-migration assay, it was found that A4K14-citropin 1.1-Sp4 had a better suppression ability of A549 cells vertical migration than a prototypical peptide at the same dose. Taking CD spectroscopy study and a protease stability experiment into account, it was suggested that protease resistance and stable spatial conformation, which were successfully optimized by stapling strategy, were both significant for the antitumor activity of A4K14-citropin 1.1 and its analogs. Besides, the improved hydrophobicity provided by fatty chains is another possible reason for increased activity.

\section{CONCLUSIONS}

In conclusion, a novel series of stapled A4K14-citropin 1.1 derivatives has been successfully realized in a satisfactory yield via the standard SPPS strategy and olefin metathesis macrocyclization. In vitro data suggested that the analog A4K14-citropin 1.1-Sp1 and A4K14-citropin 1.1-Sp4 displayed improved helicity levels, greater protease stability, and increased antitumor activity compared with the original peptide, which establishes them as promising lead compounds for novel cancer therapeutics development. In addition, considering the close relationship between stable $\alpha$-helix structure and membrane penetration ability and AMPs' molecular cellmembrane hole-punching role during the killing of pathogens, it was speculated that the antitumor mechanism of A4K14citropin 1.1 and its analogs is also related to its cell membrane

\section{REFERENCES}

Avrahami, D., and Shai, Y. (2002). Conjugation of a magainin analogue with lipophilic acids controls hydrophobicity, solution assembly, and cell selectivity. Biochemistry. 41, 2254-2263. doi: 10.1021/bi011549t

Bird, G. H., Madani, N., Perry, A. F., Princiotto, A. M., Supko, J. G., He, X. Y., et al. (2010). Hydrocarbon double-stapling remedies the proteolytic instability of a lengthy peptide therapeutic. Proc. Natl. Acad. Sci. U. S. A. 107:14093. doi: 10.1073/pnas. 1002713107

Chapuis, H., Slaninová, J., Bednárová, L., Monincová, L., Buděšínský, M., and Cerovský, V. (2012). Effect of hydrocarbon stapling on the properties of $\alpha$ helical antimicrobial peptides isolated from the venom of hymenoptera. Amino Acids. 43, 2047-2058. doi: 10.1007/s00726-012-1283-1

Cui, H. K., Qing, J., Guo, Y., Wang, Y. J., Cui, L. J., He, T. H., et al. (2013). Stapled peptide-based membrane fusion inhibitors of hepatitis C virus. Bioorg. Med. Chem. 21, 3547-3554. doi: 10.1016/j.bmc.2013.02.011

Dathe, M., and Wieprecht, T. (1999). Structural features of helical antimicrobial peptides: their potential to modulate activity on model membranes and biological cells. Biochim. Biophys. Acta. 1462, 71-87. doi: $10.1016 /$ S0005-2736(99)00201-1

Dathe, M., Wieprecht, T., Nikolenko, H., Handel, L., Maloy, W. L., MacDonald, D. L., et al. (1997). Hydrophobicity, hydrophobic moment and angle subtended by permeation property. Further molecular tracing studies using a fluorescent molecular labeling strategy and relative biological investigation are ongoing, and new findings will be published in due course.

\section{DATA AVAILABILITY STATEMENT}

The original contributions presented in the study are included in the article/Supplementary Materials, further inquiries can be directed to the corresponding author/s.

\section{AUTHOR CONTRIBUTIONS}

LF and H-GH: conceptualization and design of the study. NW and CL: synthesis of the compounds. GX, WC, and YL: performance of the pharmacological tests. SH: statistical analysis of the data. H-GH: writing and revising of the manuscript. All authors contributed to the article and approved the submitted version.

\section{FUNDING}

This work was supported by the National Nature Science Foundation of China (Nos. 91841929, 81703526, and 41806088).

\section{ACKNOWLEDGMENTS}

We thank LetPub for its linguistic assistance during the preparation of this manuscript.

\section{SUPPLEMENTARY MATERIAL}

The Supplementary Material for this article can be found online at: https://www.frontiersin.org/articles/10.3389/fchem. 2020.616147/full\#supplementary-material charged residues modulate antibacterial and haemolytic activity of amphipathic helical peptides. FEBS. Lett. 403, 208-212. doi: 10.1016/S0014-5793(97)0 0055-0

Doyle, J., Brinkworth, C. S., Wegener, K. L., Carver, J. A., Llewellyn, L. E., Olver, I. N., et al. (2003). nNOS inhibition, antimicrobial and anticancer activity of the amphibian skin peptide, citropin 1.1 and synthetic modifications. Eur. J. Biochem. 270, 1141-1153. doi: 10.1046/j.1432-1033.2003.0 3462.x

Henninot, A., Collins, J. C., and Nuss, J. M. (2018). The Current State of Peptide Drug Discovery: Back to the Future? J. Med. Chem. 61, 1382-1414. doi: 10.1021/acs.jmedchem.7b00318

Kannan, S., Aronica, P. G. A., Ng, S., Gek-Lian, D. T., Frosi, Y., Chee, S., et al. (2020). Macrocyclization of an all-d linear $\alpha$-helical peptide imparts cellular permeability. Chem Sci. 11, 5577-5591. doi: 10.1039/C9SC06383H

Kobayashi, M., Wood, P. A., and Hrushesky, W. J. (2002). Circadian chemotherapy for gynecological and genitourinary cancers. Chronobiol. Int. 19, 237-251. doi: 10.1081/CBI-120002600

Lee, Y. K., Choi, J., Wang, W., Lee, S., Nam, T. H., Choi, W. S., et al. (2013). Nullifying tumor efflux by prolonged endolysosome vesicles: development of low dose anticancercarbon nanotube drug. ACS Nano 7, 8484-8497. doi: 10.1021/ nn4041206 
Li, X., Chen, S., Zhang, W. D., and Hu, H. G. (2020). Stapled Helical Peptides Bearing Different Anchoring Residues. Chem. Rev. 120, 10079-10144. doi: 10.1021/acs.chemrev.0c00532

Liu, T. R., Cong, W., Ye, L., Xu, X. K., Liao, X. F., Xie, G., et al. (2020). Rational design of stapled peptides targeting phosphorylated GSK3 $\beta$ for regulating osteoclast differentiation. RSC Adv. 10, 7758-7763. doi: 10.1039/D0RA00008F

Lohner, K. (2017). Membrane-active antimicrobial peptides as template structures for novel antibiotic agents. Curr. Top. Med. Chem. 17, 508-519. doi: 10.2174/1568026616666160713122404

Marr, A. K., Gooderham, W. J., and Hancock, R. E. (2006). Antibacterial peptides for therapeutic use: obstacles and realistic outlook. Curr. Opin. Pharmacol. 6, 468-472. doi: 10.1016/j.coph.2006.04.006

Mortensen, A. C. L., Spiegelberg, D., Brown, C. J., Lane, D. P., and Nestor, M. (2019). The stapled peptide PM2 stabilizes p53 levels and radiosensitizes wild-type p53 cancer cells. Front. Oncol. 9:923. doi: 10.3389/fonc.2019.00923

Mourtada, R., Herce, H. D., Yin, D. J., Moroco, J. A., Wales, T. E., Engen, J. R., et al. (2019). Design of stapled antimicrobial peptides that are stable, nontoxic and kill antibiotic-resistant bacteria in mice. Nat. Biotechnol. 37, 1186-1197. doi: 10.1038/s41587-019-0222-z

Murray, C. J., and Lopez, A. D. (2013). Measuring the global burden of disease. N. Engl. J. Med. 369, 448-457. doi: 10.1056/NEJMra1201534

Pouny, Y., Rapaport, D., Mor, A., Nicolas, P., and Shai, Y. (1992). Interaction of antimicrobial dermaseptin and its fluorescently labeled analogues with phospholipid membranes. Biochemistry 31, 12416-12423. doi: 10.1021/bi00164a017

Ross, R. W., and Small, E. J. (2002). Osteoporosis in men treated with androgen deprivation therapy for prostate cancer. J. Urol. 167, 1952-1956. doi: 10.1016/S0022-5347(05)65060-4

Schafmeister, C. E., Po, J., and Verdine, G. L. (2000). An all-hydrocarbon crosslinking system for enhancing the helicity and metabolic stability of peptides. J. Am. Chem. Soc. 122, 5891-5892. doi: 10.1021/ja000563a
Shang, D., Sun, Y., Wang, C., Ma, L., Li, J., and Wang, X. (2012). Rational design of anti-microbial peptides with enhanced activity and low cytotoxicity based on the structure of the arginine/histidine-rich peptide, chensinin-1. J. Appl. Microbiol. 113, 677-685. doi: 10.1111/j.1365-2672.2012.05355.x

Tong, C. W. S., Mingxia, W., Cho, W. C. S., and To, K. K. W. (2018). Recent advances in the treatment of breast cancer. Front. Oncol. 8:227. doi: 10.3389/fonc.2018.00227

Torre, L. A., Bray, F., Siegel, R. L., Ferlay, J., Lortet-Tieulent, J., and Jemal, A. (2011). Global Cancer Statistics. CA Cancer J. Clin. 61, 134-134. doi: 10.3322/caac. 20115

Walensky, L. D., and Bird, G. H. (2014). Hydrocarbon-stapled peptides: principles, practice, and progress. J. Med. Chem. 57, 6275-6288. doi: 10.1021/jm4011675

Wang, D., Chen, K., Kulp-Iii, J. L., and Arora, P. S. (2006). Evaluation of biologically relevant short $\alpha$-helices stabilized by a main-chain hydrogen-bond surrogate. J. Am. Chem. Soc. 128, 9248-9256. doi: 10.1021/ja062710w

Wieprecht, T., Dathe, M., Beyermann, M., Krause, E., Maloy, W. L., MacDonald, D. L., et al. (1997). Peptide hydrophobicity controls the activity and selectivity of magainin 2 amide in interaction with membranes. Biochemistry 36, 6124-6132. doi: 10.1021/bi9619987

Conflict of Interest: The authors declare that the research was conducted in the absence of any commercial or financial relationships that could be construed as a potential conflict of interest.

Copyright (C) 2020 Wang, Xie, Liu, Cong, He, Li, Fan and Hu. This is an open-access article distributed under the terms of the Creative Commons Attribution License (CC $B Y)$. The use, distribution or reproduction in other forums is permitted, provided the original author(s) and the copyright owner(s) are credited and that the original publication in this journal is cited, in accordance with accepted academic practice. No use, distribution or reproduction is permitted which does not comply with these terms. 